\title{
Quatro boas novas de uma política editorial consistente e institucionalmente sustentada!
}

\section{Four good news about a consistent and institutionally supported editorial policy!}

A política editorial que orienta as atividades no âmbito de nosso periódico se encontra em vigoroso andamento. Temos quatro boas novas neste momento!

Primeiramente, é com muito orgulho, satisfação e felicidade que informamos a presença de DEMETRA em três bases internacionais de indexação de veículos que promovem acesso aberto de periódicos científicos: Open Journal Systems, Free Medical Journals e Journals for Free. Esse é apenas o início de um processo que estamos empreendendo com forte apoio do Portal de Revistas Eletrônicas da UERJ. Novas indexações virão em breve!

O segundo ponto que queremos destacar corresponde à divulgação da lista de periódicos que compõem o Qualis CAPES. Nossa revista já conta com três indicações nessa página eletrônica institucional: B4 nas áreas de Saúde Coletiva e Interdisciplinar e B5 na área de Nutrição. Começamos a escalada subindo os primeiros degraus da longa escadaria que "qualifica" a produção científica brasileira. Consideramos que nossos esforços no sentido de construir um periódico sólido, confiável e livre de conflitos de interesses merecem um olhar diferenciado por parte dos pesquisadores que atuam no interior das "Áreas de Avaliação".

Assim como tantos outros editores de revistas de acesso inteiramente gratuito para autores e leitores, operamos ação contra-hegemônica em relação ao colonialismo científico e ao verdadeiro mercado em que se transformou o espaço internacional de disseminação da produção de conhecimento no âmbito da ciência. Observemos que, no caso brasileiro, a pesquisa científica se dá basicamente a partir de recursos públicos. Este é um tema que muito nos mobiliza e ao qual daremos mais espaço em oportunidades futuras.

A terceira novidade corresponde ao fato de que estamos publicando dez artigos neste volume 8 número 2, o que corresponde ao dobro do previsto no Plano de Ação 2013. É uma grata surpresa, para todos nós editores, o recebimento de um volume bem maior de originais; isto significa que 
estamos ganhando visibilidade por parte de pesquisadores e que estes, por sua vez, estão mais confiantes em enviar seus escritos para nossa avaliação. Registremos que também estão em elevação, tanto a qualidade dos trabalhos submetidos, quanto os padrões de exigência que adotamos no processo de avaliação por pares.

Por fim, e tão importante quanto todos os itens anteriores, informamos a publicação do suplemento temático "Ciências Sociais e Humanas em Alimentação e Nutrição". Fizemos uma chamada específica para essa matéria, à qual um número surpreendentemente alto de pesquisadores respondeu com trabalhos que caracterizaram um amplo leque de "objetos" de estudo e de abordagens teóricas e metodológicas. Esse número suplementar, cuja viabilização se deve ao firme apoio institucional que recebemos da UERJ, faz parte também do movimento de crescimento de nossa DEMETRA e inclui várias novidades editoriais a serem levadas a público por ocasião de um importante evento que já se avizinha.

Aproveitamos, assim, a oportunidade colocada por este editorial para convidá-los a estar conosco no lançamento do Suplemento Temático "Ciências Sociais e Humanas em Alimentação e Nutrição", que acontecerá durante o VI Congresso Brasileiro de Ciências Sociais e Humanas em Saúde, promovido pela ABRASCO e que terá lugar na UERJ, Campus Maracanã, de 13 a 17 de novembro de 2013, nesta cidade maravilhosa do Rio de Janeiro que os receberá, a todos, de braços abertos e com o coração pleno de alegria!

Shirley Donizete Prado

Editora 